\title{
Lethal and Sterile Effects of X-ray Irradiation on Cigarette Beetle, Lasioderma serricorne (F.) (Coleoptera: Anobiidae)
}

\author{
by \\ Toshihiro Imai ${ }^{1}$, Masahiro Onozawa ${ }^{2}$, Tetsuya Takekawa ${ }^{3}$, and Taketomi Shakudo \\ ${ }^{1}$ Leaf Tobacco Research Center, Japan Tobacco Inc., Oyama, Tochigi, Japan \\ ${ }^{2}$ Cigarette Materials R\&D Div, Japan Tobacco Inc., Asaka, Saitama, Japan \\ ${ }^{3}$ NFI Irradiation Service Division, Nuclear Fuel Industries, Ltd., Kumatori, Osaka, Japan
}

\section{SUMMARY}

The effects of X-ray irradiation on mortality and sterility of the cigarette beetle, Lasioderma serricorne (F.), were studied at doses ranging from 0.05 to $0.2 \mathrm{kGy}$. Irradiation above $0.1 \mathrm{kGy}$ prevented eggs and larvae from developing to the adult stage. The irradiated larvae remained at the larval or pupal stages for months without further development and ultimately died of desiccation. Irradiation did not affect the viability of pupae and adults but seriously affected their fertility. Females were completely sterilized above $0.1 \mathrm{kGy}$, although males retained weakened fertility at all doses tested. These results suggest that X-ray irradiation at $0.1 \mathrm{kGy}$ can completely break the reproductive cycle of the cigarette beetle, even though the action is not immediate, and therefore it would be applicable for the disinfestation of stored tobacco. [Beitr. Tabakforsch. Int. 22 (2006) 1-5]

\section{ZUSAMMENFASSUNG}

Die Wirkung von Röntgenstrahlen auf die Mortalität und Sterilität des Zigarettenkäfers, Lasioderma serricorne (F.), wurde im Dosisbereich von 0.05 bis $0.2 \mathrm{kGy}$ untersucht. Eine Strahlung über $0.1 \mathrm{kGy}$ verhinderte das Erreichen ausgewachsener Entwicklungsstadien von Eiern und Larven. Die bestrahlten Larven verblieben für Monate ohne weitere Entwicklung im Larven- oder Puppenstadium und starben letztendlich an Austrocknung. Die Bestrahlung hatte keine Auswirkung auf die Lebensfähigkeit der Puppen und ausge- wachsenen Tiere, schädigte jedoch in starkem Maße ihre Fertilität. Die Weibchen wurden bei einer Strahlung über 0.1 kGy vollständig steril, wohingegen die Männchen bei allen untersuchten Dosen eine verminderte Fruchtbarkeit behielten. Diese Ergebnisse zeigen, dass eine Bestrahlung mit Röntgenstrahlen von 0.1 kGy den Reproduktionszyklus des Zigarettenkäfers vollständig zerstört, auch wenn die Wirkung nicht sofort eintritt und dieses Mittel aus diesem Grund zur Verhinderung eines Befalls von gelagertem Tabak geeignet ist. [Beitr. Tabakforsch. Int. 22 (2006) 1-5]

\section{RESUME}

Les effets des rayons $\mathrm{X}$ sur la mortalité et la stérilité de Lasioderma serricorne (F.) ont été examinés pour des doses de 0.05 à $0.2 \mathrm{kGy}$. L'irradiation de plus de $0.1 \mathrm{kGy}$ empêche le développement des oeufs et des larves au stade adulte. Les larves irradiées restent aux stades larve ou pupe pendant des mois sans développement ultérieur et finissent par mourir de dessiccation. L'irradiation n'affecte pas la viabilité des pupes et des adultes, mais atteint sérieusement leur fertilité. Les femelles sont complètement stérilisées au dessus de $0.1 \mathrm{kGy}$, bien que les mâles conservent une fertilité réduite à toutes les doses testées. Les résultats suggèrent que l'irradiation avec des rayons $\mathrm{X}$ de $0.1 \mathrm{kGy}$ puisse complètement bloquer le cycle reproductif de Lasioderma serricorne (F.), même si l'effet n'est pas immédiat et ainsi l'application est appropriée pour la désinsectisation du tabac stocké. [Beitr. Tabakforsch. Int. 22 (2006) 1-5]

*Received: $14^{\text {th }}$ September 2005 - accepted: $1^{\text {st }}$ February 2006 


\section{INTRODUCTION}

The cigarette beetle, Lasioderma serricorne (F.) is the most important pest for tobacco industries, causing serious damage to stored tobacco leaves as well as manufactured tobacco products. Cured tobacco leaves are generally stored for years in warehouses before they are manufactured into cigarettes, and the long storage period offers the opportunity of infestation and reproduction of the pests. Pesticide application to stored tobacco as well as tobacco products is restricted. Space and surface sprays of insecticides such as natural pyrethrins and synthetic pyrethroids have been applied in warehouses, however, they cannot control the insects living within packaged tobacco (1). Phosphine fumigation is the most reliable method for disinfestation at present, however, resistant beetles have been spreading and the present fumigation techniques are becoming less efficient $(2,3)$.

Controlled atmospheres and physical methods have been considered as alternatives to fumigation (1). The use of ionizing radiation has been anticipated as one of them. X-ray irradiation generated by roentgen tubes had been applied to cigars by the early 1910s when the effects had not been fully determined (4). Later, the controlling effect on the cigarette beetle was confirmed (5), however, the radiation-absorbed doses were not measured due to the lack of reliable dosimetry techniques. Then an X-ray machine with a conveyor system for the irradiation of cigars was put into operation in 1929 (6). Roentgen tubes as a source of X-ray are unsuitable for continuous use in mass production lines because of their short durability and the low dose rate, and chemical fumigation replaced this first industrial application of radiation processing (6). Since the 1950s, the effect of ionizing radiation from another source, i.e., gamma ray from ${ }^{60} \mathrm{Co}$, has been investigated. Lethal and sterilizing doses were confirmed (7-14), but gamma-ray irradiation has not been applied industrially for disinfestation of tobacco, perhaps partly due to the lack of consumer acceptance. Recently high-energy electron beam accelerators have been developed and converted X-ray generated by the accelerators became industrially available as a reliable and safer source of ionizing radiation. An accelerator can be switched on and off with no radioactive substances being involved, and, because it can generate X-ray at a much higher dose rate, it is therefore suitable for mass production lines. Effects of gamma ray, electron beam and converted Xray on microorganisms was comparatively studied (15), however, knowledge of the X-ray effects on insect pests has not accumulated to a sufficient degree. In this study, lethal and sterilizing effects of converted X-ray on the various developmental stages of the cigarette beetle were observed to establish an effective disinfestating procedure in stored tobacco.

\section{MATERIALS AND METHODS}

\section{Insect}

The cigarette beetles used in this study were of the phosphineresistant culture originally collected from fumigated stored tobacco leaves and maintained in the Japan Tobacco (JT) laboratory on $10 \%$ yeast-added corn flour under $27{ }^{\circ} \mathrm{C}$ and $60 \% \mathrm{RH}$. These conditions were kept constant throughout the experiments except for $36 \mathrm{~h}$ for irradiation at Nuclear Fuel
Industries (NFI), when both exposed and control insects experienced $23.8-30.1{ }^{\circ} \mathrm{C}$ (average $26.8{ }^{\circ} \mathrm{C}$ ) and 46-62\% RH (average $54.5 \%$ ) conditions. Males and females were sexed at the pupal stage and maintained separately. For irradiation, 50 eggs (1-2 and 5-6 days after oviposition) enveloped in paraffin paper, 30 larvae (first to second instar, 16-17 days after oviposition; second to third instar, 23-24 days after oviposition; third to fourth instar, 30-31 days after oviposition) with 8-g corn flour, 50 pupae in cotton wool and 50 adults (8-9 days after emergence, when sperm or eggs had been formed in the genital organs) were put into $2.5 \times 5 \mathrm{~cm}$ polystyrene vials respectively. Two replications for each stage were carried out.

\section{$X$-ray irradiation}

Insects in vials were exposed to X-ray generated by a tantalum $\mathrm{X}$-ray target beamed with 5-MeV electron derived from an IBA RHODOTRON accelerator. A beam current was fixed at $16 \mathrm{~mA}$, and insects were passed under the X-ray target at a distance of ca. $5 \mathrm{~cm}$. The speeds were changed from $7-28 \mathrm{~m} / \mathrm{min}$ to obtain the doses of 50-200 Gy. Exposed doses measured with ISP GAFCHROMIC D-200 dosimeters were as follows [mean (on the top-on the bottom of vial) Gy]: 55 (59-52), 105 (110-100), 155 (164-146) and 202 (215-189).

\section{Assessment of mortality and sterility}

After irradiation eggs were put on black paper with a small amount of corn flour to prevent cannibalism and hatching was observed. The hatched larvae were transferred into corn flour. The criterion for the viability of the irradiated eggs, larvae, and pupae was transition to the adult stage. The adults, irradiated at both pupal and adult stages, were paired 7-10 days after emergence in the following combination: irradiated $x$ irradiated, irradiated $\times$ control (reciprocal), control $\times$ control. Each pair of adults was kept in a $2.5 \times 5 \mathrm{~cm}$ polystyrene vial with 0.05 -g cocoa powder for a week. The eggs laid in cocoa were counted, checked for hatching and put in corn flour for observation of development to the adult stage. Ten replications for each combination were carried out. Data were transformed to $\log (x+1)$ to normalize variances and multiple means were separated with analysis of variance (ANOVA) followed by Tukey-Kramer test $(p<0.05)$.

\section{RESULTS}

The effect on eggs is summarized in Table 1. Hatches were completely suppressed when one to two day-old eggs were exposed at 55 Gy, whereas five to six day-old eggs were not affected even at the higher doses. However, the larvae hatched from exposed eggs failed to develop above $105 \mathrm{~Gy}$ and only two of 60 hatched larvae (3\%) managed to complete their development to adults at 55 Gy.

$\mathrm{X}$-ray irradiation revealed no immediate effect on larvae, but strongly inhibited growth. No adults emerged from the irradiated larvae above $105 \mathrm{~Gy}$, and two to ten adults emerged from 60 irradiated larvae (3-17\%) at 55 Gy (Table 2 ). The irradiated larvae remained at the larval or pupal stages for months without further development and finally died from desiccation. 
Table 1. Effect of X-ray on eggs of Lasioderma serricorne

\begin{tabular}{l|c|c|c|c}
\hline $\begin{array}{l}\text { Dose, } \\
\text { Gy }\end{array}$ & $\begin{array}{c}\text { Age, } \\
\text { days }\end{array}$ & $\begin{array}{c}\text { No. of eggs } \\
\text { tested }\end{array}$ & $\begin{array}{c}\text { No. of eggs } \\
\text { hatched }\end{array}$ & $\begin{array}{c}\text { No. of adults } \\
\text { emerged }\end{array}$ \\
\hline 0 & $1-2$ & 100 & 82 & 74 \\
& $5-6$ & 100 & 73 & 64 \\
50 & $1-2$ & 100 & 0 & 0 \\
& $5-6$ & 100 & 60 & 2 \\
100 & $1-2$ & 100 & 0 & 0 \\
& $5-6$ & 100 & 75 & 0 \\
150 & $1-2$ & 100 & 0 & 0 \\
& $5-6$ & 100 & 76 & 0 \\
200 & $1-2$ & 100 & 0 & 0 \\
& $5-6$ & 100 & 66 & 0 \\
\hline
\end{tabular}

Adult emergence from pupae was not affected (Table 3), but fertility was seriously suppressed (Table 4). For males emerging from the irradiated pupae, there were no significant differences in the numbers of eggs laid by their partners, however, viability of the eggs was significantly affected even at $55 \mathrm{~Gy}$. On the other hand, for females the effects on fertility were not obvious at 55 Gy, however, oviposition was significantly suppressed and viability of the eggs laid decreased to zero above $105 \mathrm{~Gy}$.

For adults no adverse effects on viability were apparent, but fertility was also severely suppressed (Table 5). For every combination, there were no significant differences in the numbers of eggs laid, but the viability of the eggs laid by irradiated females was completely lost above 105 Gy. In contrast, fertility of males was suppressed but persisted at all doses tested, although the numbers of progeny decreased significantly at all doses, except for $105 \mathrm{~Gy}$.

\section{DISCUSSION}

Lethal and sterile effects of converted X-ray were almost equivalent to those of gamma ray already reported. For pupae and adults, an effect on viability was not obvious among the doses $0.05-0.2 \mathrm{kGy}$. For eggs and larvae,
Table 3. Effect of X-ray on pupae of Lasioderma serricorne

\begin{tabular}{l|c|c|c}
\hline $\begin{array}{l}\text { Dose, } \\
\text { Gy }\end{array}$ & Sex & $\begin{array}{c}\text { No. of pupae } \\
\text { tested }\end{array}$ & $\begin{array}{c}\text { No. of adults } \\
\text { emerged }\end{array}$ \\
\hline 0 & $\sigma^{\pi}$ & 50 & 36 \\
& $\circ$ & 50 & 35 \\
50 & $\sigma^{\pi}$ & 50 & 40 \\
& + & 50 & 41 \\
100 & $\sigma^{\pi}$ & 50 & 37 \\
& + & 50 & 36 \\
150 & $\sigma^{\pi}$ & 50 & 37 \\
& + & 50 & 37 \\
200 & $\sigma^{\pi}$ & 50 & 40 \\
& + & 50 & 40 \\
\hline
\end{tabular}

growth was suppressed but death was not immediate. Agedependent variability in egg's susceptibility has also been demonstrated for gamma ray $(5,9,13)$. The minimum dose that prevented eggs and larvae from developing to the adult stage $(0.1 \mathrm{kGy})$ was within the variation reported; 0.025-0.05 kGy (13), 0.1 kGy (9), 0.1-0.15 kGy (10), 0.2 kGy (12). SuZUKI (8) and TILTON et al. (7) described the emergence of one adult each from larvae irradiated at 0.4-kGy and 1-kGy gamma ray, respectively. Even in such cases most of the irradiated larvae were killed at $0.1 \mathrm{kGy}$, and therefore, for the control of eggs and larvae, $0.1 \mathrm{kGy}$ should be sufficient in practice.

For sterilizing effect, males were less susceptible than females. A similar phenomenon has been observed in diverse species of stored product insects (16). TILTON et al. (7) described the minimum sterilizing dose of gamma ray as 250 and 175 Gy for males and females, respectively, which was a little higher than our results for X-ray. RAHIM and NORIMAH (11) described the minimum dose as $0.1 \mathrm{kGy}$ when both parents were exposed, which is identical to our finding.

X-ray irradiation at $0.1 \mathrm{kGy}$ will simultaneously attain complete growth inhibition of egg and larva and sterilization of female pupa and adult, thus it will break the reproductive cycle and annihilate the cigarette beetle. The action is not immediate, so that it would not be appropriate in the

Table 2. Effect of X-ray on larvae of Lasioderma serricorne

\begin{tabular}{|c|c|c|c|c|c|}
\hline Dose, Gy & Age, days & No. of larvae tested & No. of dead larvae & No. of dead pupae & No. of adults emerged \\
\hline \multirow[t]{3}{*}{0} & $16-17$ & 60 & 12 & 0 & 48 \\
\hline & $23-24$ & 60 & 7 & 0 & 53 \\
\hline & $30-31$ & 60 & 0 & 0 & 60 \\
\hline \multirow[t]{3}{*}{50} & $16-17$ & 60 & 38 & 12 & 10 \\
\hline & $23-24$ & 60 & 16 & 42 & 2 \\
\hline & $30-31$ & 60 & 3 & 54 & 3 \\
\hline \multirow[t]{3}{*}{100} & $16-17$ & 60 & 60 & 0 & 0 \\
\hline & $23-24$ & 60 & 57 & 3 & 0 \\
\hline & $30-31$ & 60 & 31 & 29 & 0 \\
\hline \multirow[t]{3}{*}{150} & $16-17$ & 60 & 60 & 0 & 0 \\
\hline & $23-24$ & 60 & 60 & 0 & 0 \\
\hline & $30-31$ & 60 & 41 & 19 & 0 \\
\hline \multirow[t]{3}{*}{200} & $16-17$ & 60 & 60 & 0 & 0 \\
\hline & $23-24$ & 60 & 60 & 0 & 0 \\
\hline & $30-31$ & 60 & 34 & 26 & 0 \\
\hline
\end{tabular}


Table 4. Effect of X-ray on fecundity of the adults irradiated at the pupal stage ${ }^{\text {a }}$

\begin{tabular}{|c|c|c|c|c|c|c|}
\hline $\begin{array}{l}\text { Dose, } \\
\text { kGy }\end{array}$ & $\begin{array}{c}\text { Irradiation } \\
\sigma^{\pi} \text { ㅇ } \\
\end{array}$ & $\begin{array}{c}\text { No. of pairs } \\
\text { tested }\end{array}$ & $\begin{array}{l}\text { No. of pairs } \\
\text { that laid eggs }\end{array}$ & $\begin{array}{l}\text { No. of eggs } \\
\text { laid }\end{array}$ & $\begin{array}{c}\text { No. of larvae } \\
\text { hatched }\end{array}$ & $\begin{array}{c}\text { No. of adults } \\
\text { emerged }\end{array}$ \\
\hline 0 & $-\quad-$ & 30 & 22 & $29.9 \pm 5.2 b$ & $17.7 \pm 3.4 c$ & $16.6 \pm 3.3 b$ \\
\hline \multirow[t]{3}{*}{50} & -+ & 10 & 8 & $14.5 \pm 4.4 b$ & $8.1 \pm 2.3 b c$ & $7.3 \pm 2.2 b$ \\
\hline & +- & 10 & 5 & $10.7 \pm 5.2 a b$ & $1.7 \pm 1.0 \mathrm{ab}$ & $1.0 \pm 0.6 a$ \\
\hline & ++ & 10 & 7 & $17.9 \pm 6.0 \mathrm{~b}$ & $3.4 \pm 1.0 \mathrm{abc}$ & $3.0 \pm 0.9 a b$ \\
\hline \multirow[t]{3}{*}{100} & -+ & 10 & 1 & $0.1 \pm 0.1 \mathrm{a}$ & $0 \pm 0 \mathrm{a}$ & $0 \pm 0 \mathrm{a}$ \\
\hline & +- & 10 & 3 & $8.9 \pm 5.2 \mathrm{ab}$ & $0.3 \pm 0.3 a$ & $0 \pm 0 \mathrm{a}$ \\
\hline & ++ & 10 & 1 & $0.1 \pm 0.1 \mathrm{a}$ & $0.1 \pm 0.1 \mathrm{a}$ & $0 \pm 0 \mathrm{a}$ \\
\hline \multirow[t]{3}{*}{150} & -+ & 10 & 1 & $0.4 \pm 0.4 a$ & $0 \pm 0 \mathrm{a}$ & $0 \pm 0 \mathrm{a}$ \\
\hline & +- & 10 & 4 & $19.9 \pm 10.1 \mathrm{ab}$ & $1.0 \pm 0.7 \mathrm{a}$ & $1.0 \pm 0.7 \mathrm{a}$ \\
\hline & $+\quad+$ & 10 & 1 & $0.1 \pm 0.1 \mathrm{a}$ & $0 \pm 0 a$ & $0 \pm 0 \mathrm{a}$ \\
\hline \multirow[t]{3}{*}{200} & -+ & 10 & 2 & $0.3 \pm 0.2 \mathrm{a}$ & $0 \pm 0 \mathrm{a}$ & $0 \pm 0 a$ \\
\hline & +- & 10 & 5 & $14.6 \pm 8.4 a b$ & $0.1 \pm 0.1 \mathrm{a}$ & $0.1 \pm 0.1 \mathrm{a}$ \\
\hline & ++ & 10 & 1 & $0.1 \pm 0.1 \mathrm{a}$ & $0 \pm 0 \mathrm{a}$ & $0 \pm 0 \mathrm{a}$ \\
\hline
\end{tabular}

${ }^{a}$ Data represent mean \pm standard error. Means followed by the same letters are not significantly different according to Tukey-Kramer test $(p<0.05)$.

Table 5. Effect of X-ray on fecundity of the adults ${ }^{\text {a }}$

\begin{tabular}{|c|c|c|c|c|c|c|}
\hline $\begin{array}{l}\text { Dose, } \\
\text { kGy }\end{array}$ & $\begin{array}{c}\text { Irradiation } \\
\sigma^{*}+9\end{array}$ & $\begin{array}{c}\text { No. of pairs } \\
\text { tested }\end{array}$ & $\begin{array}{l}\text { No. of pairs } \\
\text { that laid eggs }\end{array}$ & $\begin{array}{l}\text { No. of eggs } \\
\text { laid }\end{array}$ & $\begin{array}{c}\text { No. of larvae } \\
\text { hatched }\end{array}$ & $\begin{array}{c}\text { No. of adults } \\
\text { emerged }\end{array}$ \\
\hline 0 & -- & 30 & 24 & $41.1 \pm 5.6$ & $27.2 \pm 4.3 b$ & $26.4 \pm 4.2 b$ \\
\hline \multirow[t]{3}{*}{50} & $-\quad+$ & 10 & 8 & $34.1 \pm 8.1$ & $0.9 \pm 0.3 a$ & $0.7 \pm 0.3 a$ \\
\hline & +- & 10 & 4 & $15.7 \pm 9.5$ & $8.6 \pm 5.7 \mathrm{a}$ & $7.3 \pm 5.2 \mathrm{a}$ \\
\hline & $+\quad+$ & 10 & 4 & $11.0 \pm 5.2$ & $0 \pm 0 a$ & $0 \pm 0 a$ \\
\hline \multirow[t]{3}{*}{100} & -+ & 10 & 8 & $32.1 \pm 7.0$ & $0.1 \pm 0.1 \mathrm{a}$ & $0 \pm 0 \mathrm{a}$ \\
\hline & +- & 10 & 5 & $34.0 \pm 14.7$ & $12.0 \pm 5.2 a b$ & $11.7 \pm 5.1 \mathrm{ab}$ \\
\hline & ++ & 10 & 7 & $24.6 \pm 6.6$ & $0 \pm 0 a$ & $0 \pm 0 a$ \\
\hline \multirow[t]{3}{*}{150} & -+ & 10 & 9 & $35.4 \pm 7.3$ & $0.1 \pm 0.1 \mathrm{a}$ & $0 \pm 0 \mathrm{a}$ \\
\hline & +- & 10 & 6 & $23.5 \pm 11.6$ & $3.4 \pm 1.7 \mathrm{a}$ & $3.4 \pm 1.7 \mathrm{a}$ \\
\hline & ++ & 10 & 4 & $7.4 \pm 4.0$ & $0 \pm 0 a$ & $0 \pm 0 \mathrm{a}$ \\
\hline \multirow[t]{3}{*}{200} & -+ & 10 & 7 & $33.2 \pm 8.2$ & $0 \pm 0 \mathrm{a}$ & $0 \pm 0 \mathrm{a}$ \\
\hline & +- & 10 & 7 & $34.9 \pm 14.1$ & $4.1 \pm 1.9 \mathrm{ab}$ & $3.3 \pm 1.5 \mathrm{a}$ \\
\hline & ++ & 10 & 3 & $10.5 \pm 5.8$ & $0 \pm 0 a$ & $0 \pm 0 a$ \\
\hline
\end{tabular}

a Data represent mean \pm standard error. Means followed by the same letters are not significantly different according to Tukey-Kramer test $(p<0.05)$.

marketplace, but the delayed action is not a problem for warehouses. Economical and sociopolitical aspects are not considered here, but the results reveal that X-ray irradiation is a feasible technique for use as an alternative to chemical fumigation for stored tobacco.

\section{REFERENCES}

1. Ryan, L. (ed.): Post-harvest tobacco infestation control; Kluwer Academic Publishers, Dordrecht, The Netherlands, 1999.

2. Rajendran, S. and K.S. Narasimhan: Phosphine resistance in the cigarette beetle Lasioderma serricorne (Coleoptera: Anobiidae) and overcoming control failures during fumigation of stored tobacco; Internat.J. Pest Man. 40 (1994) 207-210.

3. Zettler, J.L. and D.W. Keever: Phosphine resistance in cigarette beetle (Coleoptera: Anobiidae) associated with tobacco storage in the southeastern United States;
J. Econ. Entomol. 87 (1994) 546-550.

4. Morgan, A.C. and G.A. Runner: Some experiments with Roëntgen rays upon the cigarette beetle, Lasioderma serricorne Fabr.; J. Econ. Entomol. 6 (1913) 226-230.

5. Runner, G.A.: Effect of Röntgen rays on the tobacco, or cigarette, beetle and the results of experiments with a new form of roentgen tube; J. Agric. Res. 6 (1916) 383-388.

6. Diehl, J.F.: Introduction: How it all began; in: Safety of irradiated foods (2nd ed.), Marcel Dekker, Inc., New York, 1995, pp. 1-8.

7. Tilton, E.W., W.E. Burkholder, and R.R. Cogburn: Effects of gamma radiation on Rhyzopertha dominica, Sitophilus oryzae, Tribolium confusum, and Lasioderma serricorne; J. Econ. Entomol. 59 (1966) 1363-1368.

8. Suzuki, I.: Studies on control of stored tobacco pests. VII-3 Effects of gamma-irradiation [in Japanes]; Special Bull. Hatano Tob. Exp. St. 8 (1971) 179-183. 
9. Lapis, E.B., R.S. Rejesus, and A. Parungao: Effects of gamma radiation on the survival pattern of the cigarette beetle, Lasioderma serricorne (F.) (Coleoptera: Anobiidae); Philipp. Ent. 3 (1977) 61-68.

10. Els, J.M., A.C. Thomas, W.M. De Villiers, and J.J. Matthee: The lethal effect of gamma radiation on Lasioderma serricorne; Phytophylactica 10 (1978) 127-128.

11. Rahim, M.A and Y. Norimah: Effects of gamma radiation on mortality and sterility of some stored product beetles; MARDI Res. J. 18 (1990) 99-105.

12. Ohh, M.H. and K.H. Chung: Studies on the effectiveness of gamma ray irradiation for control of cigarette beetle [in Korean with English summary], Lasioderma serricorne F. (Coleoptera: Anobiidae); Korean J. Appl. Entomol. 33 (1994) 263-269.

13. Harwalkar, M.R., T.K. Dongre, and S.R. Padwal-Desai: Radiation disinfestation of spice and spice products. I. Radiation sensitivity of developmental stages of Lasioderma serricorne and Stegobium paniceum; J. Food Sci. Technol. 32 (1995) 249-251.
14. Keever, D.W.: Mortality and sterility of the cigarette beetle, Lasioderma serricorne (F.), in cigars induced by gamma-irradiation; Tob. Sci. 43 (1999) 43-46.

15. Ito, H., Y. Ohki, Y. Watanabe, H. Sunaga, and I. Ishigaki: Sterilization of Bacillus spores by converted X rays; Radiat. Phys. Chem. 42 (1993) 597-600.

16. Tilton, E.W. and J.H. Brower: Ionizing radiation for insect control in grain and grain products; Cereal Foods World 32 (1987) 330-335.

Corresponding author:

Toshihiro Imai

Leaf Tobacco Research Center

Japan Tobacco Inc.

Idei 1900, Oyama,

Tochigi 323-0808

Japan

E-mail:toshihiro.imai@ims.jti.co.jp 